ESJ Social Sciences

\title{
Research Competence Training Model for First-Time Investigators (Panamá, Udelas)
}

\author{
Lebrija Analinnette (PhD)
}

Decana de Investigación,

Universidad Especializada de las Américas, Panamá

Montenegro Raul (B.S.)

Asistente de investigación,

Universidad Especializada de las Américas, Panamá

Kaur Harminder (MS)

Profesora Investigadora, Universidad Especializada de las Américas, Panamá

Doi:10.19044/esj.2021.v17n5p69

Submitted: 29 September 2020

Accepted: 23 February 2021

Published: 28 February 2021
Copyright 2021 Author(s)

Under Creative Commons BY-NC-ND

4.0 OPEN ACCESS

Cite As:

Analinnette L., Raul M. \& Harminder K. (2021). Research Competence Training Model for First-Time Investigators (Panamá, Udelas). European Scientific Journal, ESJ, 17(5), 69. https://doi.org/10.19044/esj.2021.v17n5p69

\section{Abstract}

Research culture is a fundamental factor in any university that promotes quality. The steppingstone in this process is the professors, who must possess the necessary knowledge, skills, and attitudes for the development of innovation and application of knowledge. This study is an action investigation, with an objective to validate a training model accompanied by the training of investigation and knowledge communities, aimed at the university professors from the Specialized University of the Americas (UDELAS). This is a descriptive field study that allows the reflection and analysis of the strengths and weaknesses of the training process of investigators in UDELAS. While conducting scientific studies, this university promotes scientific culture through the training and development of knowledge and investigation communities. These communities are formed by professors-investigators with an interest in the same line of investigation. The results indicate that professors-investigators have improved their scientific knowledge. Investigation communities have become much stronger, and participants have perceived an adequate process of accompaniment and administration. In conclusion, research culture has grown in UDELAS and it 
has been proved that the used model is efficient and has achieved its objectives.

Keywords: Teacher training in investigation, investigation, knowledge communities and investigation, research culture

\section{Introduction}

Panama has a little research culture. In recent years, due to the evaluations of the National Council for University Assessment and Accreditation (CONAUPA), the universities made an introspection of their strengths and weaknesses. This led to understanding the lack of research culture, scientific studies, and innovation. As a result, the Specialized University of the Americas begins a process of change and in 2016 proposes a model for training researchers based on scientific skills and support.

It is well-known that there are challenges around building a research culture at universities that require proper training programs (Beldarraìn, 2001; Perez, 2002). According to this perspective, Lorenzo (2012) argues that the training of researchers is the crucial aspect of achieving high-quality education in all areas of knowledge. These trends, the generation of researchers via a training program, demands to reassess the purposes and methods used in Latin America to search new and effective alternatives for propelling research at the university level. Indeed, the training of teacher-researchers is a great challenge. However, Lockman and Schirmer (2020) explained in their research that most strategies with effectiveness in the online environment tend to be the same ones that are considered useful in face-to-face classrooms. It includes the use of multiple pedagogies and learning resources to address the different learning needs of students.

Often times, research aptitude development is correlated with the completion of an academic degree (bachelor, master and doctoral degree) in any field. To challenge this notion, Villalobos and Melo (2008) proposed to create vocational programs that seek to train the faculty to achieve better professionals with a higher impact on education. However, this is not the only requirement to make research teams or learning communities with welldefined research topics (Hernández \& Flores, 2013).

The research groups must be interdisciplinary to generate knowledge and research networks that promote innovation (Luna, 2003). Furthermore, although the purpose of developing research teams is to increase scientific production, it is also essential to develop personal relationships. This also include improving the assertive communication among its members (at the group and institutional level) to enhance knowledge transfer and raise a more cohesive, dynamic, and healthy academic community at the university level. 
At the Specialized University of the Americas (UDELAS), this study focuses on developing a training model for professors-researchers through the development of learning and research communities. A community is created with professors, students, and administrative staff interested in sharing their expertise and passion learning about a specific topic of their interest (Coll, 2001; Hernández \& Flores, 2013).

It is crucial to blend teaching and research to propel innovation and diffuse state of the art knowledge into the classroom. Furthermore, this is required to provide an answer to the current scientific and technological needs of the political, economic, and cultural linings of our society (Claveria, 2009; Lopera, 2013).

Among the Latin American countries, Brazil invests the most while India secures the top position in South and West Asia with a $0.8 \%$ investment. The African Union, in Africa, set their goals at 1\%. However, only Kenya, Malí, and South Africa are close to this objective.

Figure 1A shows Panama's comparison to the world's expenditure in Research and Development (R\&D) and the other world economies. Costa Rica, which has a comparable Gross Domestic Product (GDP), invests nine (9) times more compared to Panama. The graph below depicts that Panama`s investment in research has been monotonically decreasing since 1996. Figure 1B shows it.
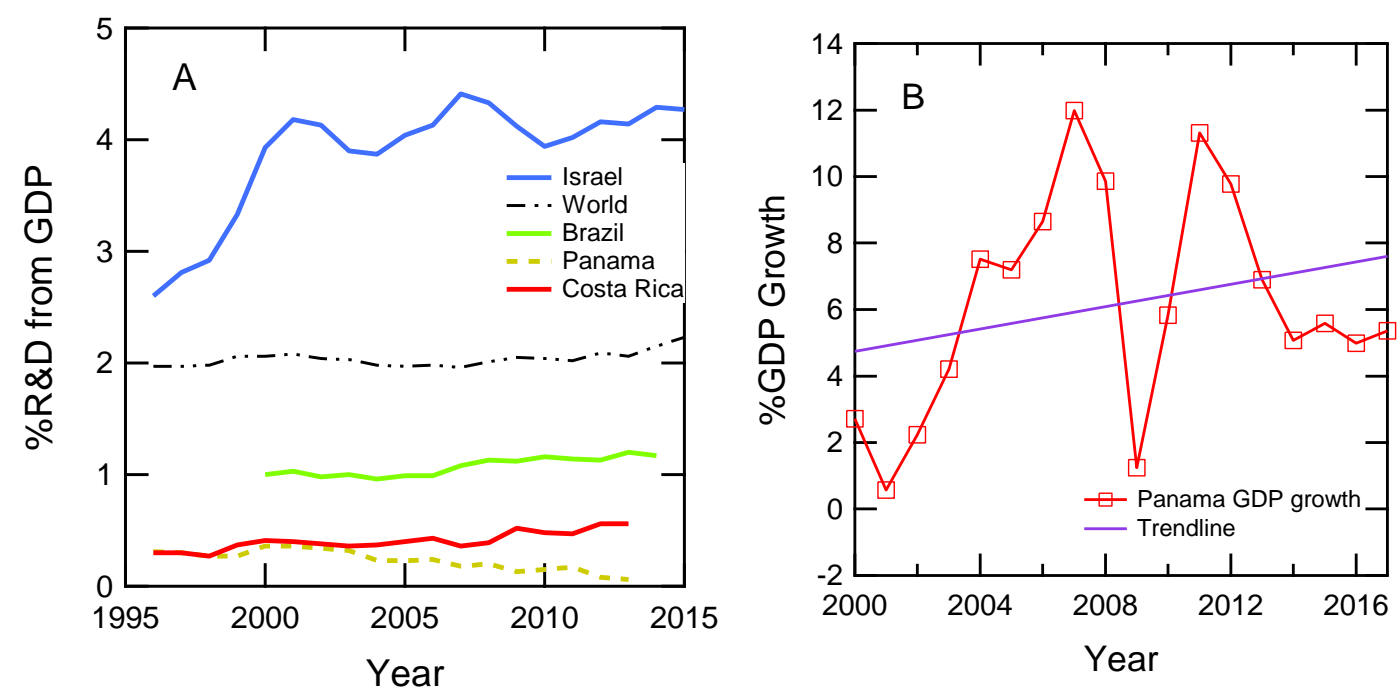

Figure 1. Percentage of GDP invested in R\&D for the world and other countries

(World Bank Group, 2013).

After undergoing a process of accreditation in 2012, UDELAS did not show consolidated research communities nor indexed publications, which was due to the lack of a clear strategy for promoting research. To advance the 
research agenda, three (3) special agreements were approved at the University Counsel to regulate the research activity. Simultaneously, it gives birth to UDELAS Research Network (REDIUDELAS). Two years later, the university created an internal research grant, and afterward, the university called for proposals once a year. From this grant, fourteen (14) active research and academic communities have been generated (Lebrija \& Morales, 2017).

Thus, the present study shows the effectiveness of a training model to train research-professors by creating research communities.

This paper focuses on validating a training model, with coaching designed for knowledge and research communities, aimed at professors of UDELAS.

\section{Theoretical Framework}

The training of researchers was implemented using different approaches such as recruitment and mobility within scientific communities, the exchange of personnel, and a system of rewards for researchers. Moreover, the training of a scientific world/community and other sociological approaches, such as analyzing the psychology of the professions, asserts that the training of researchers is an ideological building process and creation of professional paradigms (Rivas Tovar, 2004).

Consequently, the reality of the institutionalization of research in Latin American Universities is very heterogeneous. This is despite the same rhetoric used throughout the region: A teacher employs all its resources and time to keep up with the steady growth of students who need instruction, and thus one cannot dedicate much lesser time for research activities.

As a result, universities lack scientific policies and effective instruments to promote research activities. Very few higher education institutions have created the infrastructure and policies for Research and Development (R \& D) because they consider research a priority.

As a result, these institutions have taken advantage of the opportunities offered by the governmental policies (RICYT, 2016). One of the skills that training programs of researchers must promote is critical thinking, which develops a global creative and innovative vision and expression of research (Colás Bravo, González Ramírez, \& Conde Jiménez, 2014). It is the creative expression in which each researcher intertwines with the knowledge that provides meaning to their activity (Sanchez, 2008).

On the other hand, Evans (2012) argues that research training should focus on the development of the person, especially their behavior, attitudes, and thinking process. It also includes an ethical dimension that is associated with the development of their values and perception towards research. From this perspective, the internal processes aimed for training researchers 
constitute the backbone of incubating a research community (Saule, Alima \& Dildar, 2019).

Önnerfors (2007) indicates that it is essential that research training programs place a significant emphasis on strengthening the emotional aspect since it is fundamental to face the risks and uncertainty generated by the advancement of science.

The research studies of Huet et al. (2009) also focuses on this topic. According to the author, the training of attitudes is the guiding axis. Moreno (2011) proposes that there should be tutors for adequate training. They can intervene as agents and give coaching during the training process. Furthermore, Edwards et al. (2011) supported Moreno et al. and concludes that new researchers can be trained through mentors or tutors. Moreno uses the example of postgraduate students who mentor undergraduate students. Thus, this relationship between master students and bachelor students reduces the possibility of departing from a scientific career path.

In a scientific culture, the researcher's apprentice has access to two clear assets: the scientific production (which is a characteristic of being immersed in a scientific culture) and the mentor - a mediating instrument in the training process. The mentor designs and uses different techniques to achieve a specific scientific skill. This social interaction shapes the conduct of the individual, which proves to be fundamental for the cognitive change necessary for creating and developing an identity in research (Colàs Bravo, Gonzàlez Ramirez, \& Conde Jimènez, 2014).

Beliefs have a significant role to play in the development of training programs. Thus, it is a fundamental element. Professors-researchers participants receive regular training about the respective environment. These participants follow the perceptions and experiences and arrive at a conclusion. In other words, these participants construct their beliefs, and this is continuously compared with other people. So, these beliefs are modified based on this introspective analysis. This is the reason training programs must consider the personal belief system (Lebrija, 2010; Lebrija \& Morales, 2017). In the case of research, beliefs encompass the position concerning scientific practice, and it helps the researcher to control the uncertainty and ambiguity that may occur in the application of knowledge in their scientific field (Usò, 2007; Lebrija, 2010).

The knowledge and research communities are spaces for communication, exchange, and scientific interaction, which brings forth a research culture through the construction of scientific projects and lines of research (Wenger, McDermott, \& Snyder, 2002; Colàs Bravo, Gonzàlez Ramirez, \& Conde Jimènez, 2014). These communities are social and cultural transforming agents (Elboj Saso \& Oliver, 2003). 
The professor-researcher training model of UDELAS promotes cultural and scientific development by learning from research communities, cooperative work, and reciprocal teaching. It also promotes positive beliefs towards research and continuous training with coaching.

The proposed model complies with UDELAS policies that regulate the scientific processes at UDELAS. The model gets strengthened with the creation of a Research Grant ("Fondo Concursable de UDELAS"), which is financed by the university. It provides funding for research which involves doctoral students (who are part of the academic/scientific community). Besides, it also encourages young scientists to publish in a scientific journal, attend conferences, and any other research activities that can serve as a platform for showcasing UDELAS research results. It has helped to increase local and international research networks. The university manages the journal, and it is called REDES.

\section{The Model}

The model considers the research culture as a spiral movement as stated by Beldarraìn (2001). Research is part of a strategic development process for universities, whose indicators compare the scientific contribution with the progress and improvement of the university and society.

Scientific and statistical knowledge, scientific writing, a second language, and the habit of spreading knowledge via symposiums/conferences, or events of different kinds, are part of the research culture.

The model is supported by the learning community, which promotes the construction of technical and scientific knowledge through cooperative work and reciprocal teaching and sharing. Hence, this common interest promotes collective development.

It is equally important to create physical spaces for scientific communication and interaction. The model further generates a research culture through the construction of projects and lines of research (Vasquez, 2011; Colàs Bravo, Gonzàlez Ramirez, \& Conde Jimènez, 2014).

Furthermore, the communities meet weekly to analyze the objectives, achievements, challenges, and the results of their work (collaborative work and dialogue between the members) (Saenz \& Lebrija, 2014).

Indeed, university policies provide solid ground to the model. Policies promote and regulate scientific processes. Without this, it is not impossible to achieve objectivity in the decision-making processes of change and continuous development. The model is also related to Doctorate programs, research grant Fondo Concursable Scientific Networks, and Redes magazine.

Since its inception, from 2015 to 2018, the model generated a consolidated network of researchers known as "REDI-UDELAS." The current stage of the model focuses on a fundamental aspect of the promotion of 
research, i.e., diffusion. For this purpose, REDES magazine and the biennial conference of UDELAS are cornerstones.

The pre-test and the post-test determined the impact of the model. Every year, the program starts with the UDELAS Research grant (Fondo Concursable). In addition, different assessment instruments are used to analyze the effectiveness of the model, such as the research binnacle, Likert scale to measure knowledge, perceptions, beliefs, questionnaires, and openself-evaluations.

At present, it is significant to clarify that there are mature research groups that have won the grant several times. Nevertheless, the fund does not meet the need of a more mature group. As a result, the training program must get a revision to account for more experienced scientists.

The training program includes workshops every month or month and a half with research groups or communities. Each group has a tutor from the Research Deanery, who coaches and provides feedback to their work. Binnacles and portfolios also help to organize and monitor the progress of each group.

Subsequently, we determined three types of experiences that can result to the development of beliefs in research. First is the personal ones, which include all the aspects of each one's life (For example, worldviews, beliefs towards oneself to others, family, etc.) (Lebrija, 2010). Second are beliefs about research knowledge, and finally, beliefs about research in general.

Beliefs intervene in the way people feel or behave, which is considered as an indisputable personal truths. They are safeguarded by each one and get derived from experience or fantasy that has a strong evaluative and affective component. They get manifested through verbal statements or actions that justify them (Ponte, 1994; Lebrija, 2010).

From the behavior of the professors-researchers, one looks to promote proactive and positive attitudes towards the investigation. Besides, these active agents create the need for new knowledge, encourage a constant curiosity to understand the inner workings of everything, and pursue solutions for real fundamental problems in our society. Thus, it is a fundamental aspect to be a researcher (Ogundu, Amadi, \& Igrubia, 2015).

As aforementioned, the model relies on university policies to regulate scientific processes. Without this, it is impossible to achieve objectivity in decision-making processes.

The model gets implemented in the doctorate program, Fondo Concursable, Scientific Networks, and Redes magazine. By integrating the aforementioned, our university was able to shift gears towards developing a scientific culture. Figure 2 can explain the model well. 


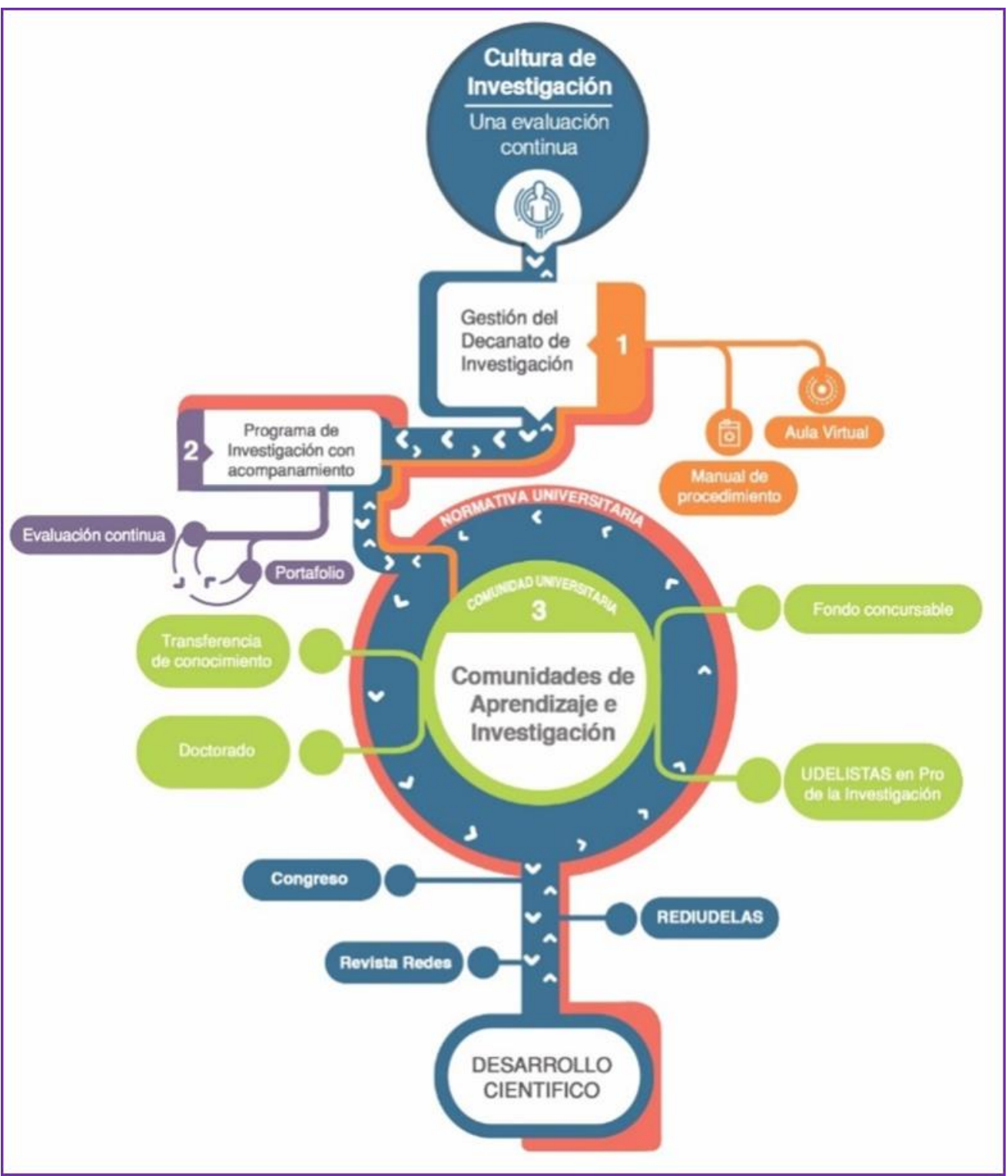

Figure 2. Training Model of the professors-investigators of UDELAS

UDELAS' teacher-researcher training model formulates scientific culture and development through learning and research communities, cooperative work, mutual teaching, the promotion of positive beliefs towards research, and continuous training with accompaniment.

On the other hand, the model is a part of the university regulations that underpin and regulate scientific processes. This is related to the doctoral academic level which is one of its core objective for the training of researchers. 
The main components of this model include Research grant, Udelas pro-research approach, Redes magazine, Redi-Udelas, and Scientific Congress.

The research grant is an action of the Specialized University of the Americas to encourage teachers' participation in scientific research. The main goal of the Udelas pro-research approach is to train student researchers to a level that they can bring significant changes into the health and education processes, or any other area of interest. The basis is formal, reliable, and scientifically valid knowledge that can help the educational quality of the Republic of Panama. The journal Redes is an official research publication of the Specialized University of the Americas, which is published once a year and it accepts articles in Spanish. Thus, it focuses on researchers, who are interested in understanding recent scientific results, in the areas of education and health.

REDI-UDELAS is a Researchers Network of the Specialized University of the Americas (REDI-UDELAS) that allows the researchers not only to create academic spaces for the training of research staff in different thematic areas of UDELAS but also facilitates the Network itself. The yearly scientific congress presents the attendees (both students and teachers or any other professional linked to education) the educational reality that we have in Panama. It depicts the different problems related to education shown through research results, and in the same way, present international research to compare the diverse educational realities and research currently existing in Panama.

Even the doctorate program at UDELAS facilitates new paradigms, changes experienced by science, and scientific knowledge in the different aerials of education. It also aims to foster academic and professional encounters between disciplines to understand an increasingly complex reality, accumulated and developing scientific knowledge.

\section{Methodology}

\section{Research Design and Type of Study}

Mixed action research which consists of validating a teacherresearcher training model through knowledge and research communities is used in the study. The evolution process is analyzed with evaluations before, during, and after the training program. It is worth clarifying that the model is applied regardless of whether the research groups have a research fund or not. This training started in 2015; however, it was in 2017 that sufficient data was obtained. The strengths, weaknesses, and effectiveness of the implementation of new tools (binnacle, portfolio, etc.) justified the validity of the model (Alvarez-Gayou, 2003). 
The present study is descriptive since it details how the research professors are building their knowledge, solving problems, and increasing their motivation. This study is more practical than theoretical. It is a selfreflective approach during the process of training and learning (AlvarezGayou, 2003; Hernández \& Flores, 2013). In addition, it allows the implementation of tools and also proffers solutions to the different problems that arise.

The research design, with mixed statistical support and a flexible intervention structure, allows us to validate the model of continuous training with coaching (through the learning and research communities) at the Universidad Especializada de las Américas (UDELAS).

The study has a quasi-experimental pretest-posttest design, in which a training program for research professors is implemented. This is achieved through coaching and a series of measurements made during the process. It is also a descriptive, explanatory, and correlation study, which seeks to contribute and analyze data to understand the effectiveness of the implemented training program. An analysis of the program includes reviewing its strengths, weaknesses, opportunities, and threats to improve the program according to the needs of the participants- researchers.

\section{Population, Group of Study, and Statistical Sample}

The population included university professors who were a group in small research and learning communities. They belonged to different campuses: Chiriqui, Veraguas, Cocle, Colon, Azuero, and Panama. The study group included communities of research professors supported by Fondo Concursable. That was the only inclusion criteria, and the sample was all the existing knowledge and research communities in the UDELAS.

\section{Variables}

- Independent Variable: Research Competency Training Model in First-time researchers through knowledge and research communities (coaching).

- Dependent variable 1: Scientific knowledge.

- Dependent variable 2: Process of building scientific knowledge.

- Dependent variable 3: Opinions and perceptions regarding the training program.

\section{Instruments}

- Likert scale for measuring the knowledge for the professors, the training process, and coaching through the research.

- Scale to measure the perception of the professors using the previous knowledge throughout the training as reference. 
- An opinion questionnaire about the strengths and weaknesses of the training process.

- Evidence Participant's Portfolio carrying evidence of learning during the process.

\section{Procedure}

In the first stage, the qualitative and quantitative instruments got validated. In the second stage, the training program's didactic materials got reviewed based on the results obtained in previous years. Upon revision, the first workshop for research professors took place. Its purpose was to increase basic scientific knowledge and develop scientific writing skills. Likewise, the professors developed a sense of community that consolidated the research groups.

The third stage focused on coaching the knowledge research communities. This was performed through a feedback process. Joint work focused on strengthening the research-scientific process by keeping a research portfolio in writing and research binnacle. During this stage, several workshops were conducted to improve skills in experimental design, research methodology, and descriptive statistics (SPSS software) among others.

In the fourth stage, the analysis of results was carried out (focusing on providing an answer to the objectives and research question), and the conclusion of the research work was written.

The data analysis contained both descriptive and inferential statistics. The knowledge level of the professors-researchers was determined using an instrument (refer to Supplementary in training S1). After then, the perception of the participants during the training and the management process got measured through means. It was obtained in 2016 and 2018, and finally, these means were compared.

Furthermore, the research portfolio and binnacle were qualitatively analyzed to describe the group's knowledge construction process. 


\section{Analysis of Results}

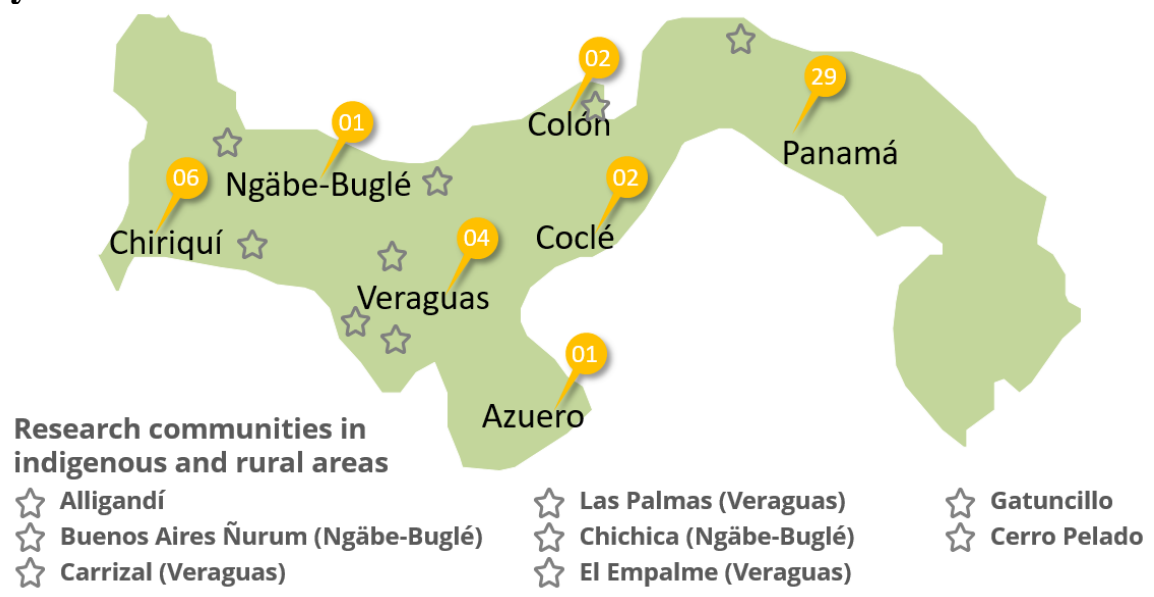

Figure 3. UDELAS' Learning and Research communities throughout Panama (up to 2017). The orange bulbs indicate the number of communities in the campuses, whereas the stars indicate those communities located in indigenous and rural areas.

Source: Research Deanery, UDELAS.

Therefore, the main objective is to validate the Training Model for first-time researchers who rely on coaching through the development of learning and research communities for UDELAS Professors.

The learning/research communities got created in 2015, the same year in which the first call was made to establish Fondo Concursable (UDELAS research grant). The Fondo Concursable is still an active program. The applicants are encouraged to participate as groups, although individuals can apply as well.

In 2015,15 researchers/research groups were awarded. Out of the 15, 13 became learning/research communities. In 2016, another new four groups joined to the already 13 established groups. In 2017, it was 11 out of 17 groups (4 of them were groups formed in 2015 and 2 were awarded as individuals). By 2017, the cumulative distribution of those communities in Panama is shown in Figure 3.

It is worth highlighting that there were few participants in 2016 because those who applied in 2015 did not finish their proposed research. Thus, only four (4) new groups were established from Fondo Concursable in 2016. Figure 4 summarizes the results. 


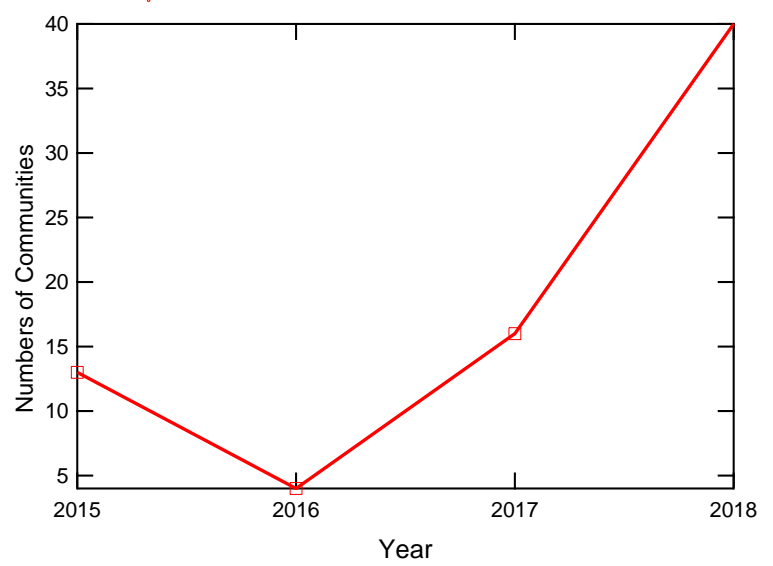

Figure 4. Learning/Research communities from 2015-2018. Source: Research Deanery, UDELAS.

From the learning/research communities formed during 2015-2016, 12 of them continue to perform research that consolidated clear lines of research.

The continuous growth in the numbers of learning/research communities indicates an increasing interest in research activities. Nonetheless, from the cumulative total of 34 created communities from 20152017, only five (5) groups dropped from the program. Out of them, four (4) groups abandoned research. Some of them started to perform administrative work while others enrolled in graduate degree programs. One of them continued with research but, now, they no longer participates in the program. In general, every year, the number of participants increased.

The current number of participants (which are agglomerated into 35 communities) involves 131 research professors. Out of them, 4 were transferred from their corresponding academic units to the Research Deanery. Those who work at the Deanery cannot apply to Fondo Concursable.

It is worth highlighting that before 2015, there were no consolidated learning/research communities in UDELAS. As a side note, UDELISTAS Pro-Research, a group of highly motivated and enthusiastic undergraduate students from the training program, got created. These undergraduate students have their research interests (topics).

Another result from the training model is that nine (9) professors, who started in the program, decided to enroll in the doctorate program. Among them, one is pursuing a doctorate abroad. It is worth mentioning that in general, since the inception of the program, the number of enrolled students in the doctorate program has increased as shown in Figure 5. 


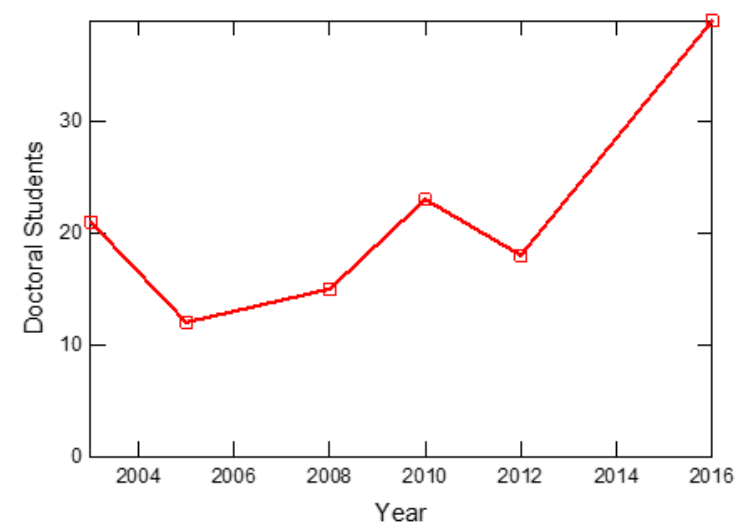

Figure 5. Students enrolled in the doctorate program by year Source: Research Deanery, UDELAS.

Among other reasons people pursue a doctorate program, one of the main reason is to deepen their knowledge and to carry out research. Thus, this shows that there is greater interest in expanding the frontiers of scientific knowledge.

At present, it is significant to notice that there are not many professors with doctorate researching in the UDELAS. Very few professors have tenure or have associate status.

In 2017 , only $2.4 \%$ of the faculty had a doctorate. As a result, only twenty-eight (28) are full-time professors and eight (8) of them works as parttime lecturers at the graduate level.

Out of them, only two (2) of them have published in indexed scientific journals (For example, Scopus, Scimago, Latindex). On the other hand, sixteen (16) of them applied and were awarded Fondo Concursable. The rest does not have a doctorate.

Furthermore, all the research professors are not thesis directors, which imply that the knowledge, research culture, and research experience from these professors are not diffusing to the undergraduate students.

The lines of research established by the communities are in public health, biomedical engineering, clinical psychology, sports psychology, learning processes, socio-educational and educational model, inclusive education, innovation, and intervention in multicultural and multilinguist societies.

The professors (participants) declared that their knowledge increased regarding the perception of the development of knowledge in the scientific method. One can notice that the percentage of those who perceived themselves as having less scientific knowledge decreased from 16\% in 2016 to $10 \%$ in 2018. Interestingly, those who perceived that their scientific knowledge was 
above average in 2016 increased to $42 \%$ in 2018 . The results are summarized in Figure 6 below.

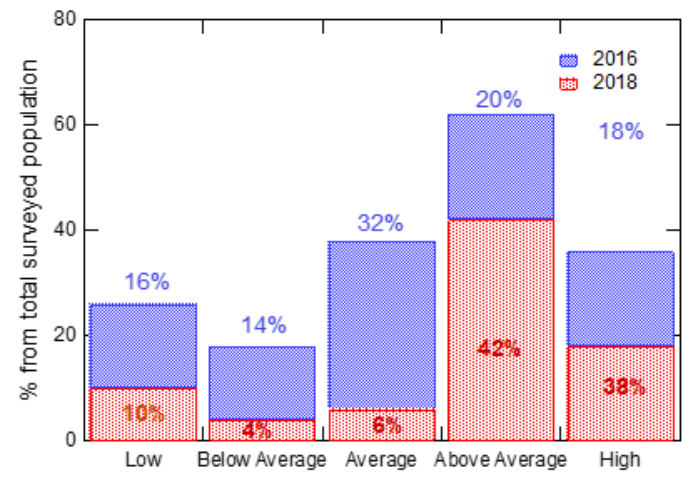

Figure 6. Perception of scientific knowledge development. Source: Research Deanery, UDELAS.

In $2016,7.5 \%$ of the respondents' professors/researchers highlighted that the strength of the program was in taking the local (national) professors/researchers. Likewise, in 2016, 35\% considered that the program's main strength was coaching. Later in 2018, 50\% of the respondents agreed that coaching was the main strength of the program. The comparative results are shown in Figure 7.

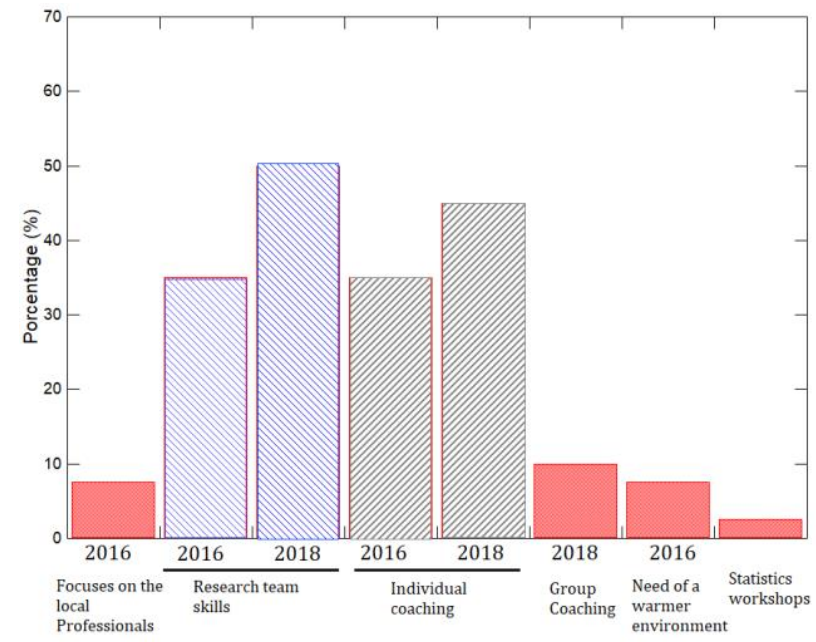

Figure 7. Strengths of the training process.

Source: Research Deanery, UDELAS, 2018

In both years, when the shortcomings of the program were analyzed (Figure 8), the respondents perceived that more coaching and follow-ups should be provided. However, in 2018, the perceived lack of coaching decreased from 2016 and which is proof that the program improved as well. 
The greatest perceived challenge from the respondents of the program is to develop technical skills (statistical analysis and writing). Table 1 summarizes the results.

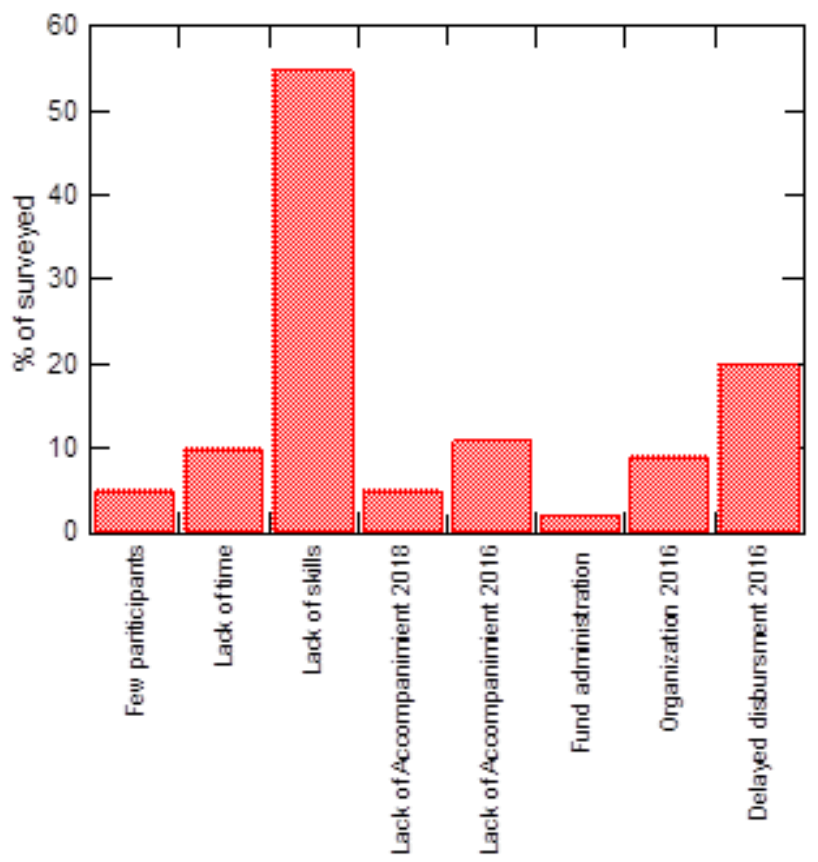

Figure 8. Challenges in the training process.

Source: Research Deanery, UDELAS, 2018

Table 1. Correlation among coaching process, management of the program and knowledge development

\begin{tabular}{|c|c|c|c|c|c|}
\hline & & & Management & $\begin{array}{l}\text { Training and } \\
\text { Coaching during } \\
\text { research }\end{array}$ & $\begin{array}{l}\text { Knowledge } \\
\text { of the method }\end{array}$ \\
\hline \multirow[t]{8}{*}{$\begin{array}{l}\text { Spearman } \\
\text { correlation }\end{array}$} & \multirow[t]{2}{*}{ Management } & $\begin{array}{l}\text { Correlation Coefficient } \\
\text { Sig. (bilateral) }\end{array}$ & & & \\
\hline & & $\mathrm{N}$ & 21 & & \\
\hline & \multirow{6}{*}{$\begin{array}{l}\text { Training } \\
\text { Process and } \\
\text { Coaching } \\
\text { Knowledge of } \\
\text { the method }\end{array}$} & Correlation coef. & $.663^{* *}$ & & \\
\hline & & Sig. (bilateral) & .001 & & \\
\hline & & $\mathrm{N}$ & 21 & 21 & \\
\hline & & Correlation Coef. & -.143 & .455 & \\
\hline & & Sig. (bilateral) & .535 & .038 & \\
\hline & & $\mathrm{N}$ & 21 & 21 & 21 \\
\hline
\end{tabular}

Figure 9 shows that the training process has a significant correlation with the management of the process because it has a strong positive correlation of 0.663. Likewise, the longer the participants stay in the program, the greater will be the scientific knowledge.

Both results support the effectiveness of the implementation of the model. Despite the deviation in Figure 9B (due to the inclusion of outliers, for 
example, professors who are eager to do research and achieve knowledge within a short period of time with few coaching), the level of significance was 0.038. Thus, this implies that there is a positive correlation between the development of scientific knowledge and the process.
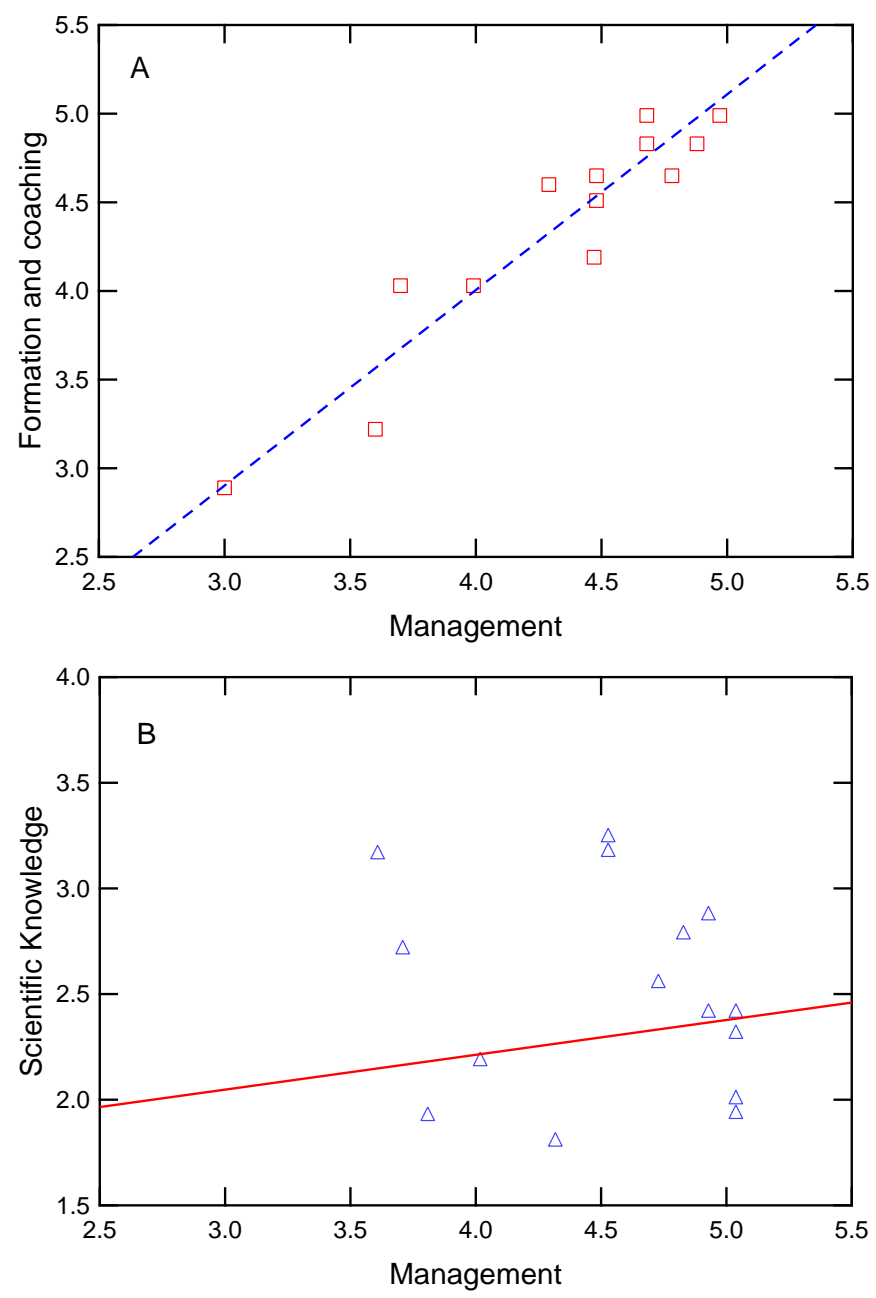

Figure 9. Correlation among coaching process, management of the program and knowledge development

If the model is to be analyzed based on the participation of the professors/researchers in conferences, it should be noted that the number of participants of the conferences organized by UDELAS also demonstrates that there is a direct correlation between the total number of keynote speakers and the training model. This can be seen from Figure 10 below. 


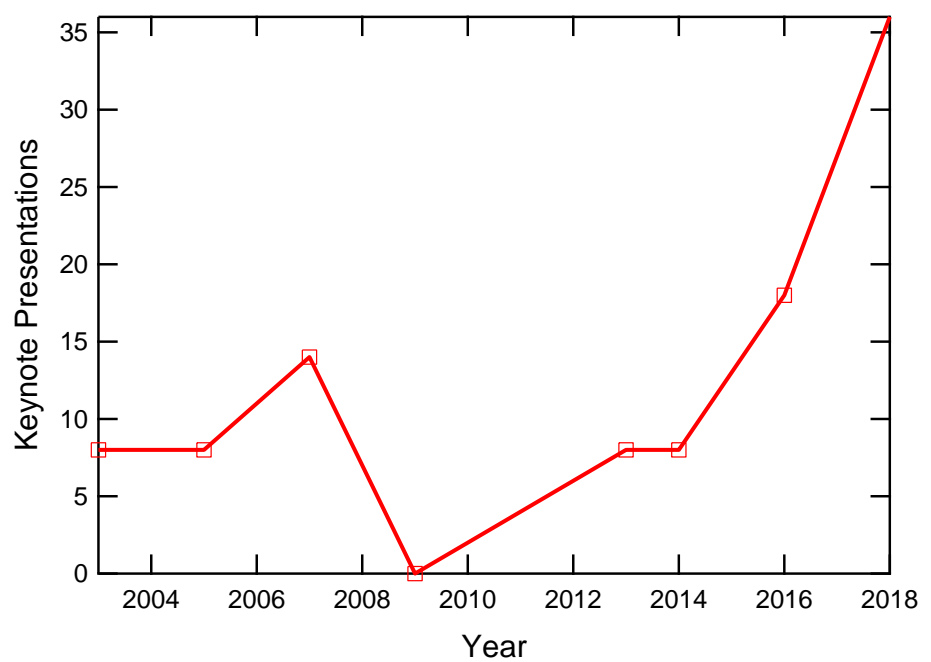

Figure 10. Scientific presentations in the UDELAS Scientific Conference, 2016. Source: Research Deanery.

The maximum number of keynote speakers was in the year 2018 . Furthermore, it is reported that there is a higher diffusion of scientific knowledge, which is related to the increased amount of registered investigations. Likewise, the number of publications in REDES and indexed journals has increased. Productivity had almost a fourfold increase in the last two years (2015-2017). A total amount of 14 versus 18 was published from 2004-2014.

REDES changed its structure in 2015 to a scientific one, and since its structure was revised, one issue is being published every year.

Regarding the research question: "Will a training program to train research professors through coaching research communities encourage research activities and scientific publishing at UDELAS?", it can be concluded that the training model has promoted scientific research in UDELAS.

\section{Conclusion}

The culture of the research intertwines with the university community. It is through the implementation of a training model with coaching and later, follow up strategy that UDELAS has improved the quality of its research. Since the university has an impressive social projection, the model helps UDELAS to contribute to the solutions of social challenges and increase the academic quality of the university (research/evidence-based decisions).

The development of learning and research communities is a way to promote and encourage professionalization in cases such as technical development in the research lines, the support of positive practices, and the 
intrinsic motivation essential for changes and growth. Professional consent should be considered and not by decree or obligation.

Despite the advances made in the learning and research communities, scientific studies show concern in research and publications. From 1,460 university professors at UDELAS, only $8.9 \%$ of university professors research the university. However, there are only a few research topics registered in Research Deanery. Furthermore, even the number of publications is even lower.

By validating the training model with coaching through the learning and research activities, the results show the advances in research that are related to each other to create a research culture that promotes the continuous development of science. It favors the academic and scientific quality of UDELAS. The results show that the training model of research competence for first-time researchers forms the basis for the scientific and innovative development of UDELAS.

\section{References:}

1. Álvarez-Gayou, J.L. (2003). Cómo hacer investigación cualitativa. Fundamentos y metodología. México. México: Editorial Paidos.

2. Beldarrain, E. (2001). En torno al término cultura. Horizontes: Revista de la Pontificia Universidad Católica de Puerto Rico, 43, 179-191. Available at:

https://dialnet.unirioja.es/servlet/articulo?codigo $=4912581$

3. Claveria, A. (2009). Investigación y docencia: factores claves en la formación y práctica pedagógica del profesor. Reflexão e Ação, 17(2), p.197-224. Available at: http://dx.doi.org/10.17058/rea.v17i2.878

4. Colás Bravo, P., González Ramírez, T. \& Conde Jiménez, J. (2014). La formación investigadora (I). Modelos Pedagógicos. Barcelona: Universidad de Barcelona. Available at: http://diposit.ub.edu/dspace/bitstream/2445/53640/6/REUNID_La_fo rmaci\%C3\%B3n_investigadora_2014.pdf.

5. Coll, C. (2001). Comunidades de Aprendizaje y el futuro de la educación: el punto de vista del Fórum Universal de las Culturas Barcelona-2004. Simposium Internacional sobre Comunidades de Aprendizaje. Organizado por el Fórum Universal de las Culturas Barcelona -2004. Barcelona, 5-6 de octubre de 2001. Available at http://www.tafor.net/psicoaula/campus/master/master/experto1/unida d16/images/ca.pdf

6. Edwards, T. M., Smith, B. K., Watts, D. L., Germain-Aubrey, C. C., Roark, A. M., Bybee, S. M., Cox, C. E., Hamlin, H. J. \& Guillette, L. J. (2011). Group-Advantaged Training of Research (GATOR): A Metamorphosis of Mentorship. BioScience, 61 (4), 301-311. Available 
at: https://www.researchgate.net/publication/232663416_GroupAdvantaged_Training_of_Research_GATOR_A_Metamorphosis_of_ Mentorship

7. Elboj Saso, C. \& Oliver, E. (2003). Las comunidades de aprendizaje: Un modelo de educación dialógica en la sociedad del conocimiento. Revista Interuniversitaria de Formación del Profesorado, 17(3), 91103. Available at: https://www.redalyc.org/pdf/274/27417306.pdf.

8. Evans, L. (2012). Leadership for researcher development: What research leaders need to know and understand. Educational Management Administration \& Leadership, 40(4), 423-435. Available at: https://journals.sagepub.com/doi/10.1177/1741143212438218

9. Hernández, A. \& Flores, R. (2013). Caracterización de una comunidad de práctica orientada al uso de la matemática en la enseñanza de la ingeniería. Innovación Educativa, 13(62), 101-119. Available at: https://www.ipn.mx/assets/files/innovacion/docs/Innovacion-

Educativa-62/IE-62.pdf

10. Huet, I., Baptista, A. V., Costa, N., Jenkins, A. \& Abelha, M. (2009). Evaluation of Under graduate Students' Involvement in Research Projects. The International Journal of Learning, 16 (9), 575588.Available at: http://hdl.handle.net/11328/990

11. Lebrija, A. (2010). Programa de formación continúa para el profesorado de matemática desde un enfoque de enseñanza centrado en el alumno, tesis doctoral, Universidad Autónoma de Madrid, Madrid, España. Available at: https://repositorio.uam.es/handle/10486/5344

12. Lebrija, A. \& Morales, L. (2017). Formación de profesores investigadores a través de comunidades de aprendizaje e investigación. European Journal of Education Studies, 3(6), 579-600. Available at: https://oapub.org/edu/index.php/ejes/article/view/779/2214

13. Lockman, A. \& Shirmer, B. (2020). Online Instruction in Higher Education: Promising, Research-based, and Evidence-based Practices. Journal of Education and e-Learning Research, 7(2), 130-152.

14. Lopera, L.V. (2013). Factores académicos, administrativos y de investigación para lograr la calidad de la formación investigativa de los alumnos de las Facultades de educación. Investigación Educativa, 17(2), 143-167. Available at: https://revistasinvestigacion.unmsm.edu.pe/index.php/educa/article/d ownload/8215/7164/

15. Lorenzo, M. (2012). Los formadores de profesores: El desafío de enseñar enseñando. Profesorado: Revista de Curriculum y formación del profesorado, 16(2), 343-360. Available at: http://www.ugr.es/ recfpro/rev162COL3.pdf 
16. Luna, M. (2003). Itinerarios del conocimiento: formas, dinámicas y contenido. Un enfoque de redes (N 13). México: Anthropos Editorial.

17. Moreno, M. (2011). La formación de investigadores como elemento para la consolidación de la investigación en la universidad. Revista de la educación superior, 40(158), 59-78. Available at: http://www.scielo.org.mx/pdf/resu/v40n158/v40n158a4.pdf.

18. Ogundu, I., Amadi, S. \& Igrubia, V. (2015). The efectos of teacher constructed furnace on students' performance in heat treatment in technical colleges in Rivers States, Nigeria. European scientific Journal, 11 (16), 369-381. Available at: http://eujournal.org/index.php/esj/article/view/5875

19. Önnerfors, A. (2007). From Scientific Apprentice to Multi-skilled Knowledge Worker: changes in $\mathrm{Ph}$. D education in the Nordic-Baltic Area. European Journal of Education Research, Development and Policy, 42(3), 321-333. Available at: https://doi.org/10.1111/j.14653435.2007.00309.x

20. Pérez, L. (2002). La ausencia de una cultura de investigación, ¿un problema de investigación formativa?. Uni-Pluri/versidad, 2(3), 16-18. Available at: https://revistas.udea.edu.co/index.php/unip/article/view/12227

21. Ponte, J. P. (1994). Mathematics teachers' professional knowledge (plenary conference). In J. P. Ponte \& J. F. Matos (Eds.), Proceedings of the 18th conference of the International Group for the Psychology of Mathematics Education 1, 195-210. Lisbon, Portugal. Available at: https://files.eric.ed.gov/fulltext/ED383537.pdf

22. Ricyt, R. I. (2016). El Estado De La Ciencia 2016 Principales Indicadores de Ciencia y Tecnología Iberoamericanos / Interamericanos 2016. Iberoamerica: RICYT. Available at: http://www.ricyt.org/2016/12/el-estado-de-la-ciencia-2016/

23. Rivas Tovar, L. A. (2004). La formación de investigadores en México. Perfiles latinoamericanos, 12(25), 89-113. Recuperado en 27 de julio de 2020, de http://www.scielo.org.mx/scielo.php?script=sci_arttext\&pid=S0188$76532004000200004 \& \operatorname{lng}=$ es\&tlng=es.

24. Sáenz, C. \& Lebrija, A. (2014). La formación continua del profesorado de matemáticas: una práctica reflexiva para una enseñanza centrada en el aprendiz. Revista latinoamericana de investigación en matemática educativa, 17(2), 219-244.

https://dx.doi.org/10.12802/relime.13.1724

25. Sánchez, L. (2008). Proceso de formación del investigador en el área tecnológica: El caso de los programas de Postgrado del CENIDET. Revista de la educación superior,37(145), 7-23. 
Recuperado en 27 de julio de 2020, de http://www.scielo.org.mx/scielo.php?script=sci_arttext\&pid=S0185$27602008000100001 \& \operatorname{lng}=\mathrm{es} \& \operatorname{lng}=$

26. Saule. P., Alima, N. \& Dildar, K. (2019). Trilingual Education in Kazakhstan: motivation and attitude of science teavhers in Learning English. European scientific Journal, 15 (25), 168-181. Available at: http://eujournal.org/index.php/esj/article/view/12384

27. Usò, L. (2007). La enseñanza / aprendizaje de la pronunciación Creencias de los profesores de E/LE sobre la enseñanza / aprendizaje de la pronunciación. Tesis doctoral, Universidad de Barcelona, Barcelona, España. Available at:

https://www.tdx.cat/TESIS_UB/AVAILABLE/TDX-0930108134627//LUV_TESIS.pdf

28. Vásquez, S. (2011). Comunidades de práctica. Educar, 47(1), 51-68. Available at:

https://www.raco.cat/index.php/Educar/article/view/244622

29. Villalobos, A. \& Melo, Y. (2008). La formación del profesor universitario: Aportes para su discusión. Universidades, 39, 3-20. Available at:

https://biblat.unam.mx/hevila/UniversidadesMexicoDF/2008/no39/1. pdf

30. Wenger, E., McDermott, R., \& Snyder, W. (2002). Cultivating Communities of Practice: A Guide to Managing Knowledge. Boston, Massachussetts: Harvard Business School Press.

31. World Bank Group (2013). Global financial development report 2014: Financial inclusion (Vol. 2). World Bank Publications. Available at: http://documents.worldbank.org/curated/en/225251468330270218/Gl obal-financial-development-report-2014-financial-inclusion 